\title{
Leaf litter and moss-inhabiting flea beetles of Hong Kong (Coleoptera: Chrysomelidae: Alticini)
}

\author{
Albert F. DAMAŠKA ${ }^{1)} \&$ Paul ASTON2) \\ 1) Department of Zoology, Faculty of Science, Charles University, Viničná 7, 12800 Prague, Czech Republic; e-mail: albert.damaska@natur.cuni.cz \\ 2)2F, 102 Wang Tong, Mui Wo, Lantau, Hong Kong; e-mail: paulaston70@hotmail.com
}

\author{
Accepted: \\ $28^{\text {th }}$ March 2019 \\ Published online: \\ $8^{\text {th }}$ April 2019
}

\begin{abstract}
The flea beetles (Coleoptera: Chrysomelidae: Galerucinae: Alticini) inhabiting leaf litter and moss in Hong Kong are reviewed and summarized for the first time. Five species are listed from Hong Kong, four of which are newly described: Benedictus sagittalis sp. nov., Cangshanaltica sprynari sp. nov., Clavicornaltica doeberli sp. nov. and C. longipenis sp. nov. Ivalia excavata (Wang, 1993) is recorded from Hong Kong for the first time. All species are photographed and their species identity is discussed.
\end{abstract}

Key words. Coleoptera, Chrysomelidae, Alticini, moss-inhabiting flea beetles, urban biodiversity, taxonomy, China, Hong Kong

\section{Introduction}

The flea beetle fauna of leaf litter and moss cushions form an understudied ecological group of beetles, in which many new genera and species have been described in recent years (LiNZMEIER \& KONSTANTINOv 2018, RUAN et al. 2017, DAMAŠKa \& Konstantinov 2016, KonstANTINOv et al. 2013, Konstantinov \& Konstantinova 2011). In Asia, the most species-rich moss-inhabiting flea beetle genera are Ivalia Jacoby, 1887 (77 known species) and Benedictus Scherer, 1969 (27 known species). However, the leaf litter and moss dwelling genus Clavicornaltica Scherer, 1974 also appears to be an extremely species-rich genus with many undescribed species (SuENAGa \& Yoshida 2016, Konstantinov \& DucKETT 2005). The flea beetle fauna of Hong Kong, one of the most populated administrative areas in the world, was summarized once before (Aston 2009). In total, 35 species of flea beetles were listed for Hong Kong, including one species of Ivalia, which was mentioned as probably undescribed. In this paper, we present a contribution to the knowledge of the flea beetle fauna of Hong Kong by providing a study of previously unknown moss-inhabiting and leaf litter inhabiting flea beetles, including a description of the aforementioned Ivalia, now revised as Cangshanaltica Konstantinov et al., 2013.

\section{Material and methods}

The examined specimens were collected by several different collectors using different collection methods (sifting, pitfall traps, individual collecting) and were organized by Paul Aston during a decade long entomological survey of Hong Kong Coleoptera. Some specimens were fixed in absolute alcohol and dried after treating with proteinase $\mathrm{K}$, which caused some of the specimens to become very fragile. The specimens were dissected; genitalia were preserved on mounting cards with the respective specimen, in a drop of water-soluble dimethyl-hydantoin-formaldehyde resin (DMHF). Photographs were taken by Canon EOS 550D, Canon EOS 70D and using an Olympus BX40 microscope. The morphological terminology is based on LAWRENCE et al. (2010). Specimens are preserved in following collections:

ADPC Albert F. Damaška collection, Prague, Czech Republic;

AFCD Agriculture, Fisheries and Conservation Department, Cheung Sha Wan Insect Collection, Hong Kong, China (M. Ying, C. Lau);

NMPC Department of Entomology, National Museum, Prague, Czech Republic (L. Sekerka);

PCPA Paul Aston collection, Hong Kong, China;

SYSU Museum of Biology, School of Life Sciences, Sun Yat-sen University, Guangzhou, China (H. Pang, F.- L. Jia);

UABG Ulf Arnold collection, Berlin, Germany;

USNM National Museum of Natural History, Smithsonian Institution, Washington DC, USA (A. S. Konstantinov). 


\section{Taxonomy}

Benedictus sagittalis sp. nov.

$$
\text { (Figs 1A-I) }
$$

Type locality. China, Hong Kong, New Territories, Castle Peak. Type material. HoLOTYPE: $\delta^{2}$ 'China: Hong Kong - New Territories; Castle Peak, pitfall trap, 30. vi. - 3. vii. 2015 R. Ho Lee et Y. Luo lgt.' (NMPC). PARATYPES: 2010 , 2 , 1 USNM, 1 SYSU, 1 PCPA); 1 , 'China: Hong Kong - New Territories, Tai Mo Shan, pitfall trap; 9. - 12. vi. 2015, R. H. Lee \& Y. Luo lgt. // VOUCHER SPECIMEN no. AFD-024 DNA isolated $2017 \mathrm{ex}$ coll. A. F. Damaška' (AFCD); 1 , 'China: Hong Kong - New Territories, Tai Mo Shan, pitfall trap; 9. - 12. vi. 2015, R. H. Lee \& Y. Luo lgt. // VOUCHER SPECIMEN no. AFD-023 DNA isolated 2017 ex coll. A. F. Damaška' (NMPC).

Differential diagnosis. This species belongs to the genus Benedictus as it has a distinct antebasal transverse impression and posteriorly open procoxal cavities, i.e. a combination of characters unique for Benedictus among apterous moss and leaf litter inhabiting flea beetles in Asia. Benedictus sagittalis sp. nov. is easily distinguishable from all other species of the genus in having a completely unique, arrow-like apex of the aedeagus (Fig. 1H).
Description. Habitus (Figs 1A-C). Body $1.7 \mathrm{~mm}$ long, $1.1 \mathrm{~mm}$ wide in maximum, oval in dorsal view, strongly convex in lateral view, $0.8 \mathrm{~mm}$ high in maximum. Color of all body surfaces light brown, eyes black, basal margins of pronotum and elytra somewhat darkened.

Head hypognathous, triangular. Frontal calli subtriangular, distinct, but feebly projecting, nearly connected to each other. Interantennal space flat, projecting, finely chagrined. Vertex shiny, impunctate. Antennae 11-segmented. Antennomere I wide, antennomere II bulbose, antennomere III thinner and shorter than I and II. Antennomeres IV-XI gradually widening. Frontal ridge strongly projecting, wide in interantennal space and strongly narrowing below. Space on sides of frontal ridge strongly and widely depressed, depressions finely chagrined, surrounded anteriorly by longitudinal edges between antennal insertions and anterior margins of clypeus. Labrum with shallow notch in middle of anterior margin, dark brown, long, about $1.2 \times$ as wide as long, with four long setae. Anterior margin of clypeus darker than head, clypeus with six setae (two pairs of setae laterally and one pair in the middle of clypeus).
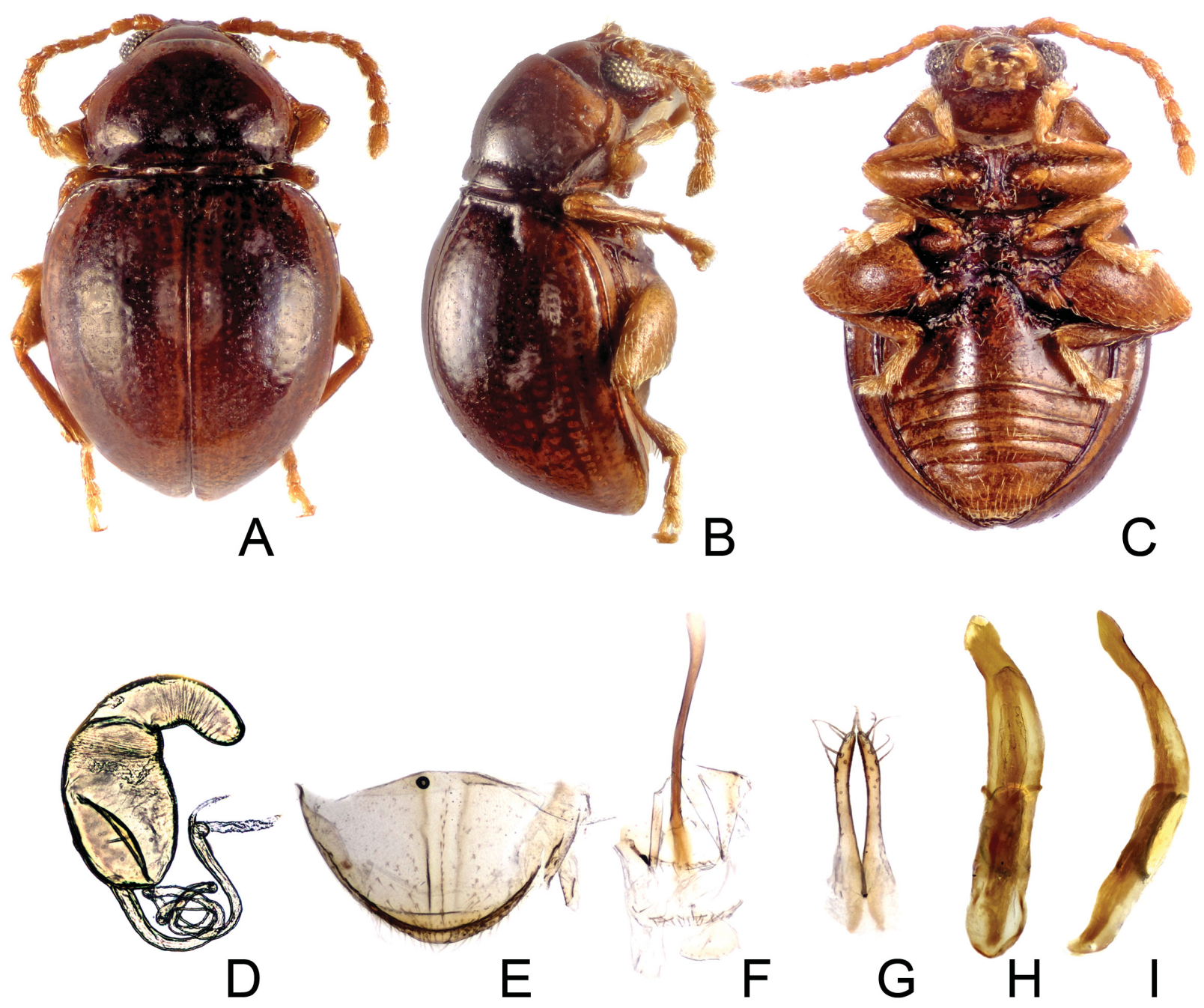

Fig. 1. Morphology of Benedictus sagittalis sp. nov. A - habitus in dorsal view; B - habitus in lateral view; C - habitus in ventral view; D - spermatheca; $\mathrm{E}$ - apical sclerite; $\mathrm{F}$ - tignum; $\mathrm{G}$ - vaginal palpi; $\mathrm{H}$ - aedeagus in dorsal view; $\mathrm{I}$ - aedeagus in lateral view. 
Thorax. Pronotum very convex, $1.3 \times$ as wide as long, anterolateral and posterolateral margins of pronotum projecting, posterolateral corners of pronotum sharp, basal pronotal transverse impression deep, with row of punctures. Elytra strongly convex, with 11 well-developed rows of small punctures. Basal part of epipleura very wide, strongly narrowing to elytral apex. Legs light brown, metatibia straight, apex of metatibia pilose, metatibial spine slender and short, metatarsomere I about $0.8 \times$ as long as metatarsomeres II and III combined. Anterior coxal cavities open, intercoxal prosternal process surpassing coxae and feebly widening posteriorly.

Abdomen with five visible ventrites, ventrite I nearly as long as ventrites II-V combined. Ventrite II slightly longer than III, ventrites III and IV equally long. Ventrite V as long as ventrites II and III combined.

Genitalia. Aedeagus (Figs 1H-I) long, with basal part slightly wider than apical, apex of aedeagus with distinct pointed arrow-like ending. Spermatheca (Fig. 1D) with receptacle bulbose, pump wide and long. Duct directing posteriorly, forming three round loops and then directing anteriorly. Vaginal palpi (Fig. 1G) long, slender, converging apically. Tignum simple (Fig. 1F).

Etymology. The name is inferred from Latin sagitta meaning 'arrow', and refers to the distinctive shape of the apex of the aedeagus. Adjective.
Biology. The specimens were found in pitfall traps in mountain areas. Other species of Benedictus are considered to be leaf litter or moss-inhabiting. We cannot clearly justify $B$. sagittalis is a moss-inhabitant, but it can be considered at least as a ground-living, leaf litter-inhabiting forest beetle, as it was found only in pitfall traps.

\section{Cangshanaltica sprynari sp. nov. \\ (Figs 2A-I, 7A-E)}

Ivalia sp. n.: Aston (2009): 11 (note).

Type locality. China, Hong Kong, Lantau Island, Wang Tong. Type material. Holotype: $\widehat{O}$, 'China: Hong Kong - Lantau isl., Wang Tong 8. viii. 2010 Paul Aston lgt. (NMPC). PARATYPes: $1 \delta 2$, same locality label as the holotype and additional label 'Genus Ivalia det. Döberl 2010' (1 $\precsim$ USNM, 1 \&YSU, 1 SMPC); 1 \%, 'China: Hong Kong - Lantau isl., Sunset Peak floating in river below waterfall, 27. ix. 2009 Paul Aston lgt.' (PCPA); 1 ô, 'China: Hong Kong - Lantau isl., Wang Tong, on moss; 9.iii.2009. Paul Aston lgt.' (AFCD); 1 , 'China: Hong Kong - Lantau isl., Wang Tong, on moss; 15. xi. 2008 Paul Aston lgt.' (ADPC).

Differential diagnosis. This new species belongs to the genus Cangshanaltica based on following characters: (1) pronotal anterolateral setiferous pore placed in the middle of the pronotal side margin; and (2) antennomere VII with a distal protrusion. Cangshanaltica sprynari $\mathrm{sp.}$ nov. differs from all other species of Cangshanaltica by following characters: (1) round anterior pronotal margins
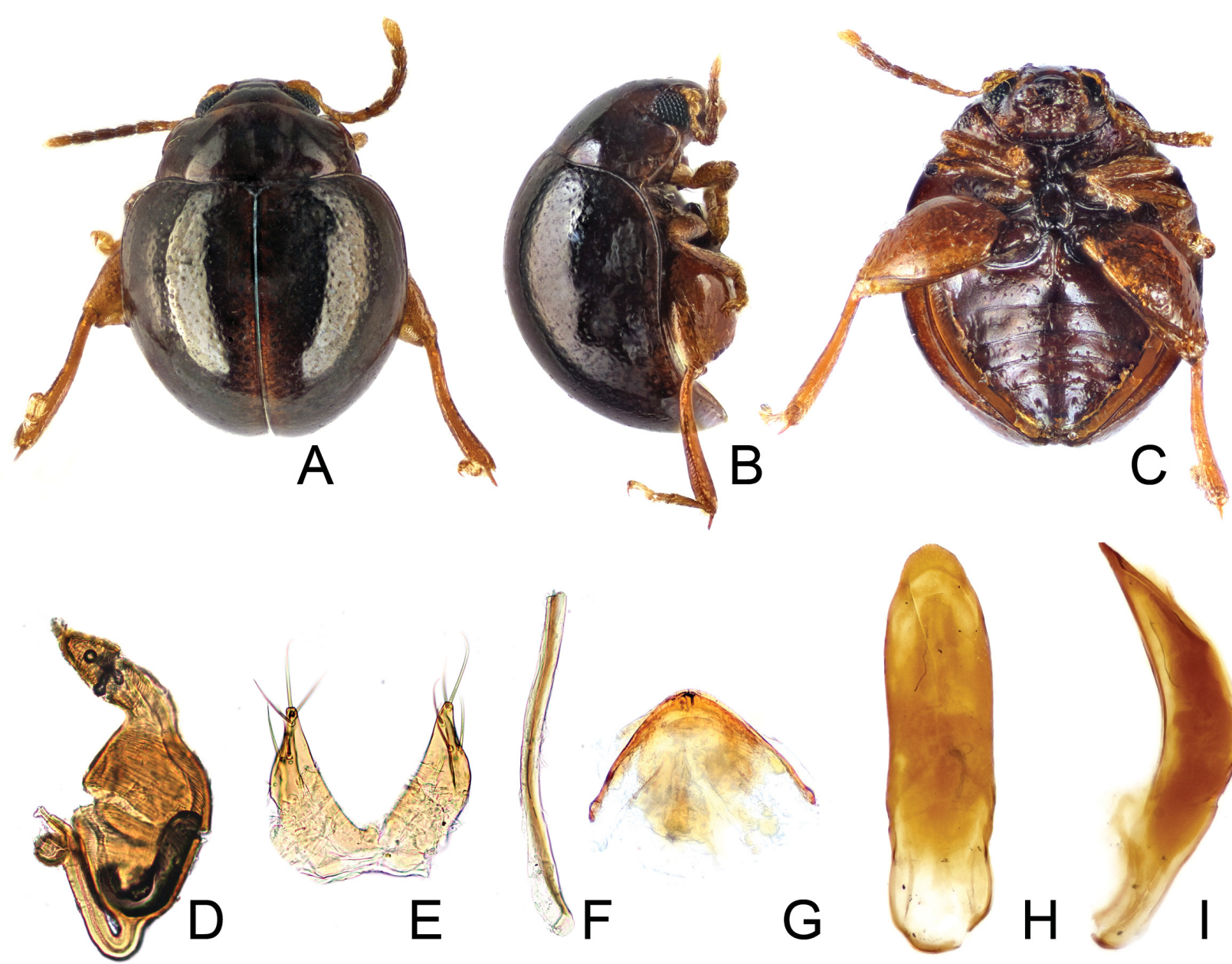

Fig. 2. Morphology of Cangshanaltica sprynari sp. nov.. A - habitus in dorsal view; B - habitus in lateral view; C - habitus in ventral view; D - spermatheca; E - vaginal palpi; $\mathrm{F}$ - tignum; $\mathrm{G}$ - apical sclerite; $\mathrm{H}$ - aedeagus in dorsal view; $\mathrm{I}$ - aedeagus in lateral view. 
(other species have anterior pronotal margins somewhat sharp), (2) short, broad and strongly diverging vaginal palpi (other species have long, slender and parallel vaginal palpi), and (3) nearly undivided frontal calli (C. nigra Konstantinov et al., 2013 has poorly developed frontal calli, C. siamensis Damaška \& Konstantinov, 2016 has distinctly divided triangular frontal calli). The species differs from $C$. nigra in brown coloration (C. nigra is black), in the shape of the aedeagus (C. nigra has the apex of the aedeagus gradually narrowing, $C$. sprynari has a narrow apex of the aedeagus, distinctly divided by a visible, abruptly narrowing step), in the shape of vaginal palpi (C. nigra has parallel and long vaginal palpi, vaginal palpi of $C$. sprynari are short, broad and strongly diverging), development of frontal calli (in C. nigra, frontal calli are nearly invisible) and metatarsomere III long (in C. nigra, the metatarsomere III is very short). The species also differs from $C$. siamensis in the shape of the aedeagus ( $C$. siamensis has a distinctly pointed apex) and in having a bulbose spermathecal receptacle (C. siamensis has a slender receptacle).

Description. Habitus (Figs 1A-C). Body $1.7 \mathrm{~mm}$ long, $1.3 \mathrm{~mm}$ wide in maximum, oval-rounded in dorsal view, convex in lateral view, $1 \mathrm{~mm}$ high in maximum. Color of both ventral and dorsal body surface dark brown, legs light brown, eyes black.

Head nearly hypognathous. Frontal calli present, flat, feebly visible, indistinctly divided, distinctly surrounded ventrally and dorsally by longitudinal impressions. Interantennal space wide. Antennae with 11 antennomeres, antennomeres $\mathrm{I}-\mathrm{V}$ and XI light brown, antennomeres VI-X darker. Antennomere VII bearing distal protrusion anteriorly. Antennomere I triangular, antennomere II oval, antennomeres III-XI regularly elongate. Maxillary palpi light brown. Frontal ridge broad, flat. Clypeus bearing two groups of three setae each, situated symmetrically on each side. Labrum bilobed, with incision reaching $1 / 4$ of labrum length, bearing six large setae in posterior parts and some scattered smaller setae on anterior margin.

Thorax. Pronotum convex, twice as wide as long, sparsely covered with shallow punctures, anterior pronotal margins strongly rounded, posterior pronotal edges sharp. Elytra strongly convex with irregular punctation, punctures larger and deeper than those on pronotum. Metathoracic wings and humeral calli absent. Metatibiae curved in dorsal view, pilose, with exterior row of teeth reaching from proximal $1 / 4$ of length of metatibia to apex. Metatibial teeth gradually elongate apically. Metatarsus attached on metatibia in deep apical impression surrounded externally by long external teeth and internally by short apical row of long teeth. Metatarsomere I 2-3× longer than II, metatibial apical tooth as long as metatarsomere II.

Abdomen with five distinct ventrites. Ventrite I as long as II and III combined, with II slightly longer than III. Longitudinal ridge on ventrite I long, reaching 2/3 of its length.

Genitalia. Aedeagus (Figs 2H-I) long, curved and broad in lateral view, parallel-sided in ventral view, apex abruptly narrowed in step-like fashion in apical eighth of aedeagus. Spermathecal pump long, receptacle bulbose, duct simple, short, directed parallel with the receptacle, reaching $1 / 2$ of receptacle length (Fig. 2D). Vaginal palpi short, broad, strongly diverging, bearing group of long setae (Fig. 2E). Tignum long, slender, simple (Fig. 2F).

Etymology. The species is named in honor of Pavel Špryňar, a Czech botanist and entomologist, who has contributed to Czech entomology by hosting an entomological club for children in Prague.

Biology. The specimens were collected at night, walking on the surface of a thin layer of moss covering stones in secondary forest growth and orchard, near Wang Tong village, Lantau, Hong Kong (Figs 7A-B). Cangshanaltica sprynari $\mathrm{sp}$. nov. appears to be active only at night, they usually begin to occur two hours after dusk (P. Aston frequently visits the locality during the day and early evening, finding no specimens) and only in periods of humidity or rainfall, never found when the moss is totally dry. One specimen was collected, with many other terrestrial beetles, in a stream after being washed away in heavy rainfall.

Host plant. One of us (PA) found the beetles feeding on moss Fissidens sp., Fissidentaceae (Figs 7C-D). Also the gut contained the residua of moss (Fig. 7E).

\section{Clavicornaltica Scherer, 1974}

The genus Clavicornaltica is represented by very small (0.6-1.5 mm long), round and strongly convex beetles of brown to nearly black color. The genus is simply distinguishable from all other Oriental flea beetle genera by the presence of clavate antennae, which are unique among Alticini - the only other genus with clavate antennae and rounded, tiny body shape known to date is Kiskeya Konstantinov \& Chamorro-Lacayo, 2006. This genus is distributed in the Carribean and is not likely related to Clavicornaltica (Konstantinov \& ChamorRo-LACAYO 2006). The identification of Clavicornaltica species is, however, extremely difficult. First described species (SCHERER 1974) were documented without the description of genitalia, because the dissection of genitalia is very complicated. Clavicornaltica species are generally uniform externally, however vary in small details of their bodies which led to a erroneously wide concept of every species and multiple forms ('form A', 'form B', etc.) were described to demonstrate small morphological nuances, which were understood as intraspecific variability (MEDVEDEV 1996). However, recent studies (Konstantinov \& DucKetT 2005, Suenaga \& Yoshida 2016) revealed that Clavicornaltica species are externally similar, but can be distinguished by examination of their genitalia. The former broad concept of Clavicornaltica species was therefore abandoned and new species are diagnosed primarily by characters on both male and female genitalia. However, this study shows that also careful searching for external characters is necessary in Clavicornaltica studies, because in one collecting event, multiple externally uniform species can be found. 


\section{Clavicornaltica doeberli sp. nov.}

(Figs 3A-H, 5A, D)

Type locality. China, Hong Kong, Hong Kong Island, HK University Campus.

Type material. HoLотурE: 0 , 'China: Hong Kong - Hong Kong isl., HK University Campus, disturbed secondary forest, sifting; 13. xi. 2014, B. Guénard lgt.' (NMPC). PARATYPES: 2 a 5 옹 same labels as holotype $(1) 1+\mathrm{AFCD}, 1$ 1 1 SYSU, 1 NMPC, 1 A $\mathrm{ADPC}, 1+\mathrm{PCPA}) ; 1$ 3. 'China: Hong Kong - Hong Kong isl., HK University Campus, disturbed secondary forest, sifting; 12. xi. 2014, B. Guénard lgt.' (ADPC); 1 , 'China: Hong Kong - Hong Kong isl., Lung Fu Shan 19. xi. 2014, Winkler, B. Guénard leg.' (UABG); 4 qq, 'China: Hong Kong - Hong Kong isl. Lung Fu Shan 18. xii. 2014, B. Guénard leg.' (1 \& NMPC, 1 ○ PCPA, 1 ㅇ SYSU, 1 + $\mathrm{AFCD})$

Differential diagnosis. This species is very similar to two species described from Vietnam - C. longsheng Konstantinov \& Duckett, 2005 and C. vietnamensis Konstantinov \& Duckett, 2005 in having an unusual shape of spermatheca with a long, slender receptacle. From $C$. longsheng, it differs by following characters: (1) posterior process of the metaventrite only slightly convex in the middle (in $C$. longsheng, the metaventrite has a high ridge in its middle part); (2) long receptacle and pump of spermatheca with spermathecal duct directed to the pump (in C. longsheng, the pump is wider, the receptacle shorter and the duct is initially directed downwards and after running length of the receptacle, it is curved back to its base); (3) long vaginal palpi with three apical setae (in $C$. longsheng, vaginal palpi have four apical setae). From $C$. vietnamensis, the new species differs in following characters: (1) base of the spermathecal duct situated before the apex of the receptacle (in C. vietnamensis, the duct base is situated directly on the apex of the receptacle); (2) slender, not widening apices of vaginal palpi (in C. vietnamensis, apices of vaginal palpi are somewhat widened); (3) body very convex dorsoventrally (in C. vietnamensis, the body is less convex dorsoventrally, especially the elytra); (4) aedeagus robust, basal opening wide, basal part of the median lobe slender, apex of the aedeagus flat (in C. vietnamensis, orificium basale is slender and the shape of the median lobe gradually narrows from the base to apex, apex of aedeagus is pointed). In the shape of the body, the species is very similar to sympatric $C$. longipenis sp. nov., but differs
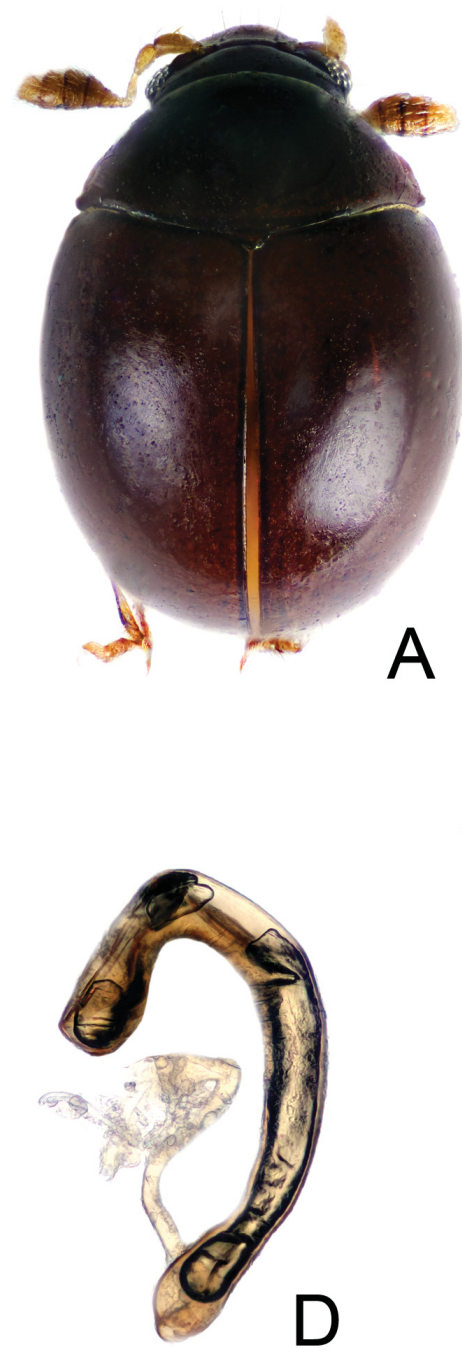
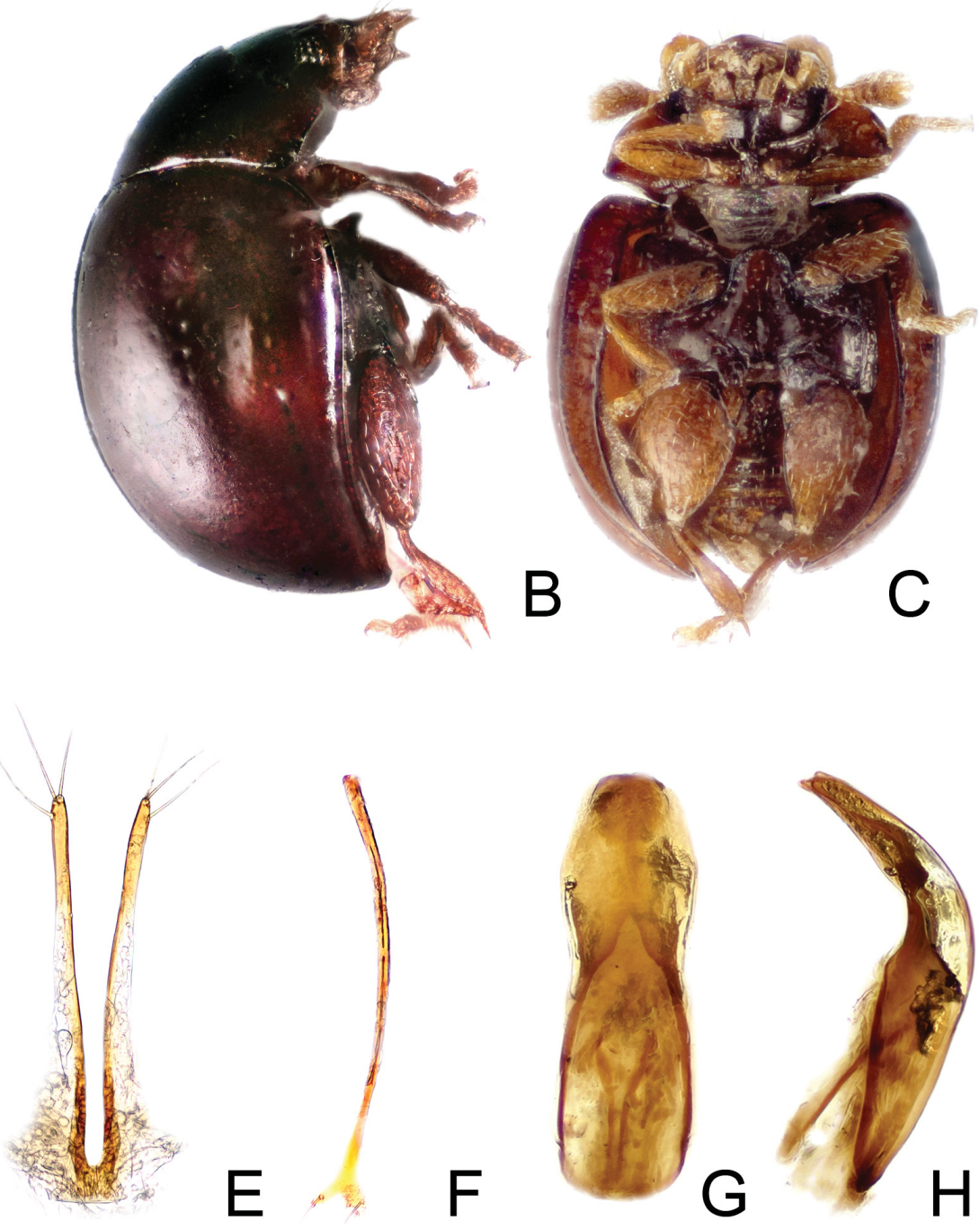

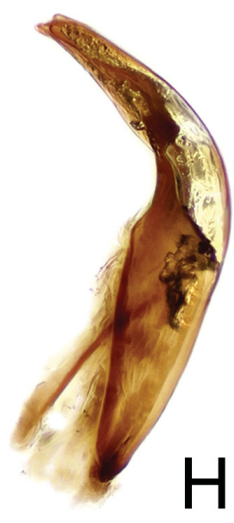

Fig. 3. Morphology of Clavicornaltica doeberli sp. nov.. A - habitus in dorsal view; B - habitus in lateral view; C - habitus in ventral view; D - spermatheca; E - vaginal palpi; F - tignum; $\mathrm{G}$ - aedeagus in dorsal view; $\mathrm{H}$ - aedeagus in lateral view. 
in having (1) metaventral process slightly convex with deep punctures on basal margins of the process (Fig. 3C), while in $C$. longipenis, metaventrite is very flat, wide and nearly impunctate (Fig. 4C); (2) wide and short aedeagus with flat apex (in $C$. longipenis, aedeagus is extremely slender with very elongate orificium basale and pointed apex); (3) C-shaped spermatheca with slender receptacle and voluminous pump (in C. longipenis, spermatheca has bulbose receptacle and a small, slender pump); (4) male macropterous (in C. longipenis, male is brachypterous); (5) intercoxal abdominal process arrow-like, nearly pointed (Fig. 5A), while in C. longipenis, intercoxal abdominal process has flat apex (Fig. 5B); (6) antennomere XI nearly rectangular (Fig. 5D), while in C. longipenis, antennomere 11 has elongated posterior edge (Fig. 5E).

Description. Habitus (Figs 3A-C). Body round, strongly convex in lateral view, $1.1 \mathrm{~mm}$ long in maximum, $0.9 \mathrm{~mm}$ wide in maximum, $0.5 \mathrm{~mm}$ high in maximum. Color of all dorsal surfaces dark reddish brown, ventral parts of thorax darkened, appendages yellowish to reddish brown.

Head hypognathous, triangular. Vertex and frons impunctate, frons with extremely feebly visible small frontal calli. Eyes big, eye diameter equal to interantennal distance or greater. Eyes connected with long frontal groove, distally surrounding frontal calli and proximally touching antennal insertions. Clypeus wide with groups of some setae between antennal insertions and margin of clypeus. Labrum feebly incised, with two pairs of long setae and one short seta placed between each pair. Antennae forming club, yellowish brown. Antennomere I long, triangular, bulbose, antennomere II bulbose, narrowing apically, antennomere III slightly longer than II, slender, slightly curved, antennomere IV extremely short and nearly reduced, antennomeres $\mathrm{V}$ and VI extremely short and small, rounded to triangular, antennomere VII slightly broader than VI, antennomeres VIII and IX short and strongly broadening gradually, antennomere $\mathrm{X}$ broad, but shorter than IX, antennomere XI nearly rectangular. Antennomeres VII-XI forming antennal club. Antennomeres I-III covered with few scattered setae, antennal club densely pilose by white setae. Clypeus wide with groups of some setae between antennal insertions and margin of clypeus. Labrum feebly incised, with two pairs of long setae with one short seta placed between setae in each pair.

Thorax. Pronotum covex, $1.9 \times$ as wide as long. Elytra convex, with feeble punctation. Punctures shallow, arranged in 11 regular rows, punctures decreasing in size towards elytral apex. Epipleuron wide, reaching $4 / 5$ of elytral length. Tibiae slightly curved, widened apically. Metatibia with apical spur having three wide teeth. Metasternum slightly convex. Metasternal process long, rounded, wide, reaching beyond mesocoxae and covering entire mesocoxal area, moderately convex with deep marginal row of deep punctures and well developed margin, surface shining with two converging rows of feeble punctures and scattered setae. Males with developed hind wings, females wingless.

Abdomen with five ventrites (Fig. 5A). Intercoxal process of ventrite I with long, narrow apex. Anterior margins of ventrite I with row of deep punctures. Carina of ventrite
I surrounded by deep punctures, which are also present at base of intercoxal process.

Genitalia. Aedeagus (Figs 3G-H) short, not projecting to thorax, median lobe bent dorsally in lateral view, orificium basale forming $60 \%$ of aedeagus length, wide, forming spine-like basal incision of median lobe. Median lobe rhomboid with dull, flat apex. Spermatheca (Fig. 3D) big, pump slender to bulbose, receptacle long and slender, duct $\mathrm{L}$ shaped, base of the duct situated before the apex of the receptacle. Vaginal palpi (Fig. 3E) connected basally, long, slender, bearing 3 long setae apically. Tignum (Fig. 3F) simple, long.

Etymology. The species is named in honor of Manfred Döberl, a memorable German entomologist and contributor to flea beetle research, who passed away in 2016 .

\section{Clavicornaltica longipenis sp. nov.}

(Figs 4A-H, 5B, C, E)

Type locality. China, Hong Kong, Hong Kong Island, Lung Fu Shan. Type material. HоLотуре: $\sigma^{7}$ 'China: Hong Kong-Hong Kong isl. Lung Fu Shan 18. xii. 2014 B. Guénard leg.' (NMPC). PARATYPES: 3 o 4 , 9 ,

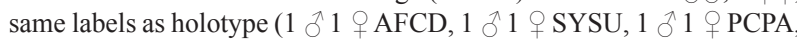
19 NMPC); $2 \circ \circ$, 'China: Hong Kong - Hong Kong isl., Lung Fu Shan 19. xi. 2014, Winkler, B. Guénard leg.' (1 + PCPA, 1 q NMPC); 1 'China: Hong Kong - New Territories, Tai Mo Shan, pitfall trap; 9. - 12. vii. 2015, R. H. Lee \& Y. Luo lgt. // VOUCHER SPECIMEN no. AFD-008 DNA isolated 2017 ex coll. A. F. Damaška' (ADPC); 1 9 'China: Hong Kong - New Territories, Tai Mo Shan, pitfall trap; 9. - 12. vii. 2015, R. H. Lee \& Y. Luo lgt. // VOUCHER SPECIMEN no. AFD025 DNA isolated 2017 ex coll. A. F. Damaška' (ADPC).

Differential diagnosis. The new species is similar to the Taiwanese Clavicornaltica mizusawai Suenaga \& Yoshida, 2016. It resembles it in having (1) a short, projecting, U-shaped spermathecal duct (in C. mizusawai, the duct follows closely the receptacle and exceeds $1 / 2$ of the receptacle length), and (2) aedeagus slender, very long, strongly curved and pointed apically, orificium basale extremely long and slender, forming $2 / 3$ of the total length of the aedeagus (in C. mizusawai, the aedeagus is short and robust, not very curved apically, with orificium basale wide and a round, dull apex). The spermatheca of C. longipenis is also somewhat similar to spermatheca of C. takizawai Döberl, 2009, but in C. takizawai, the duct is very simple, following parallel to the receptacle (in C. longipenis, the duct is shorter and U-shaped). Clavicornaltica longipenis also conspicuously differs from C. takizawai in having an impunctate frons (C. takizawai has a strongly punctate frons) and by the morphology of the aedeagus (in C. takizawai, aedeagus is shorter and broad, similarly to C. mizusawai in proportions and not curved apically). Externally, the new species resembles sympatrically living C. doeberli sp. nov., see the diagnosis of the latter species. The species also resembles $C$. dali Konstantinov \& Duckett, 2005 in having flightless males and an extremely long orificium basale of aedeagus, but in $C$. dali, the aedeagus is robust and strongly widened before apex (in C. longipenis, aedeagus is only slightly widened, nearly paralell-sided, and very slender).

Description. Habitus (Figs 4A-C). Body round, very convex in lateral view, $1.1 \mathrm{~mm}$ long, $0.8 \mathrm{~mm}$ wide in 

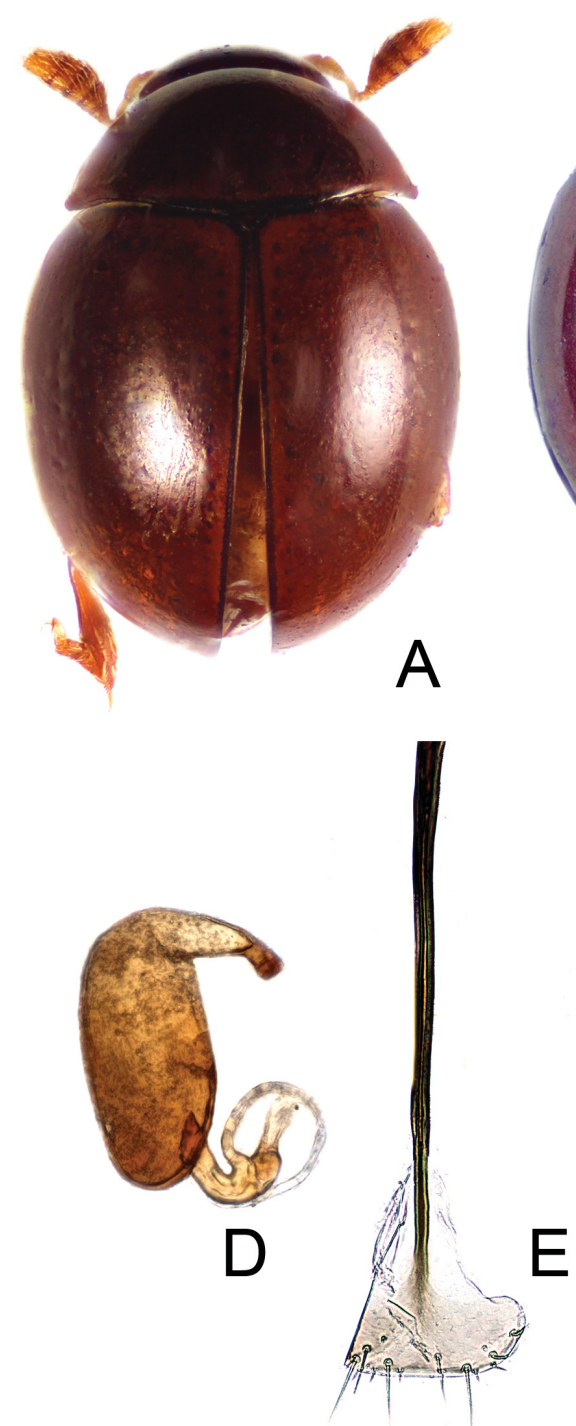

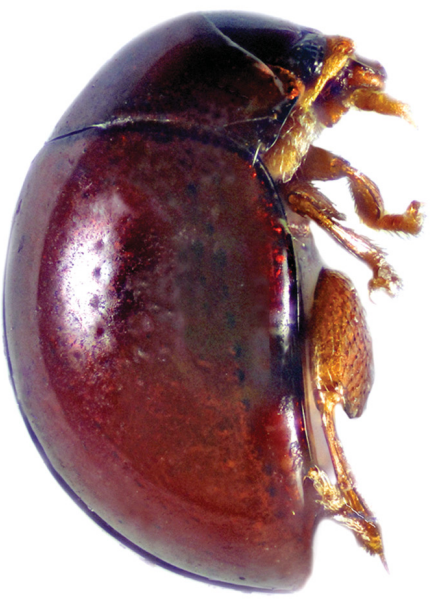

B

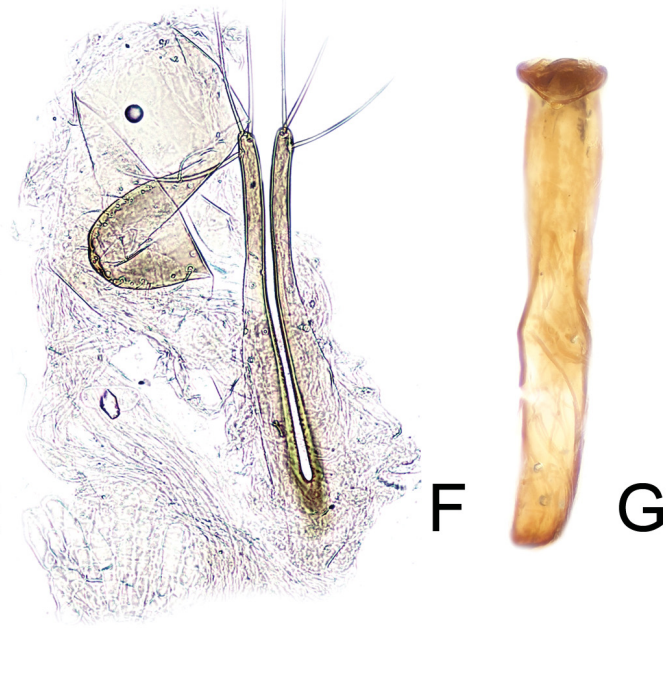

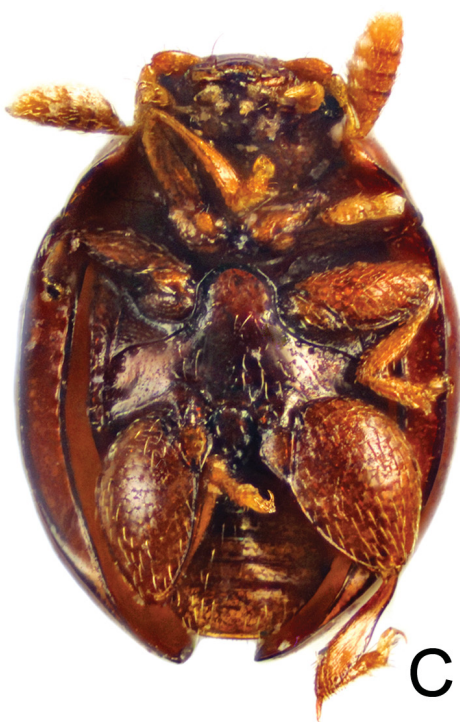

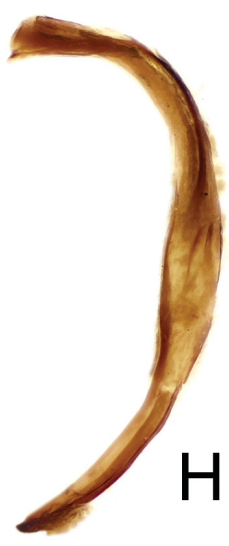

Fig. 4. Morphology of Clavicornaltica longipenis sp. nov.. A - habitus in dorsal view; B - habitus in lateral view; C - habitus in ventral view; D - spermatheca; $\mathrm{E}$ - tignum; $\mathrm{F}$ - vaginal palpi; $\mathrm{G}$-aedeagus in dorsal view; $\mathrm{H}$ - aedeagus in lateral view.

maximum, $0.6 \mathrm{~mm}$ of maximum height. Color of dorsal surface dark reddish brown, ventral parts of thorax darkened, appendages yellowish to reddish brown.

Head hypognathous, triangular. Vertex and frons impunctate, frons with extremely feebly visible small frontal calli. Eyes small, eye diameter equal to or smaller than interantennal distance. Eyes connected to antennal insertions by deep groove, frons bare, frontal groove disappearing between antennal insertions. Clypeus feebly narrowed with groups of setae between antennal insertions and margin of clypeus. Labrum incised, with two pairs of long setae. Antennae forming club, yellowish brown. Antennomere I triangular, bulbose, antennomere II long, triangular, narrowing apically, antennomere III equally long or slightly shorter than II, slender, slightly curved, antennomere IV extremely short and nearly reduced, antennomeres V and VI short and small, antennomere VII slightly broader than VI, antennomeres VIII and IX short and strongly widening, antennomere $\mathrm{X}$ broad, but shorter and longer than IX, antennomere XI round triangular, incised apically. Antennomeres VII-XI forming antennal club. Antennomeres I-III covered with few scattered setae, antennal club densely pilose by white setae. Clypeus feebly narrowed with groups of some setae between antennal insertions and margin of clypeus. Labrum incised, with two pairs of long setae.

Thorax. Pronotum convex, $2.1 \times$ as wide as long. Elytra convex, slightly punctate, punctures arranged in 11 regular rows, puncture size gradually decreases towards elytral apex. Epipleura wide, reaching $4 / 5$ of elytra. Tibiae slightly curved, widened apically. Metatibia with apical spur with one, two or none wide teeth. Metaventrite flat. Metaventral process long, rounded, wide, reaching beyond mesocoxae and covering entire surface of mesoventrite, flat with shallow marginal row, forming small punctures basally, and with developed marginal edge, surface shining with some scattered setae. Males brachypterous with wing reduced to small winglets (Fig. 5C), females wingless.

Abdomen with five ventrites (Fig. 5B). Intercoxal process of ventrite I with short, wide apex. Anterior margins of ventrite I with row of deep punctures. Carina of ventrite I surrounded by deep punctures at base of intercoxal process, intercoxal process impunctate. 

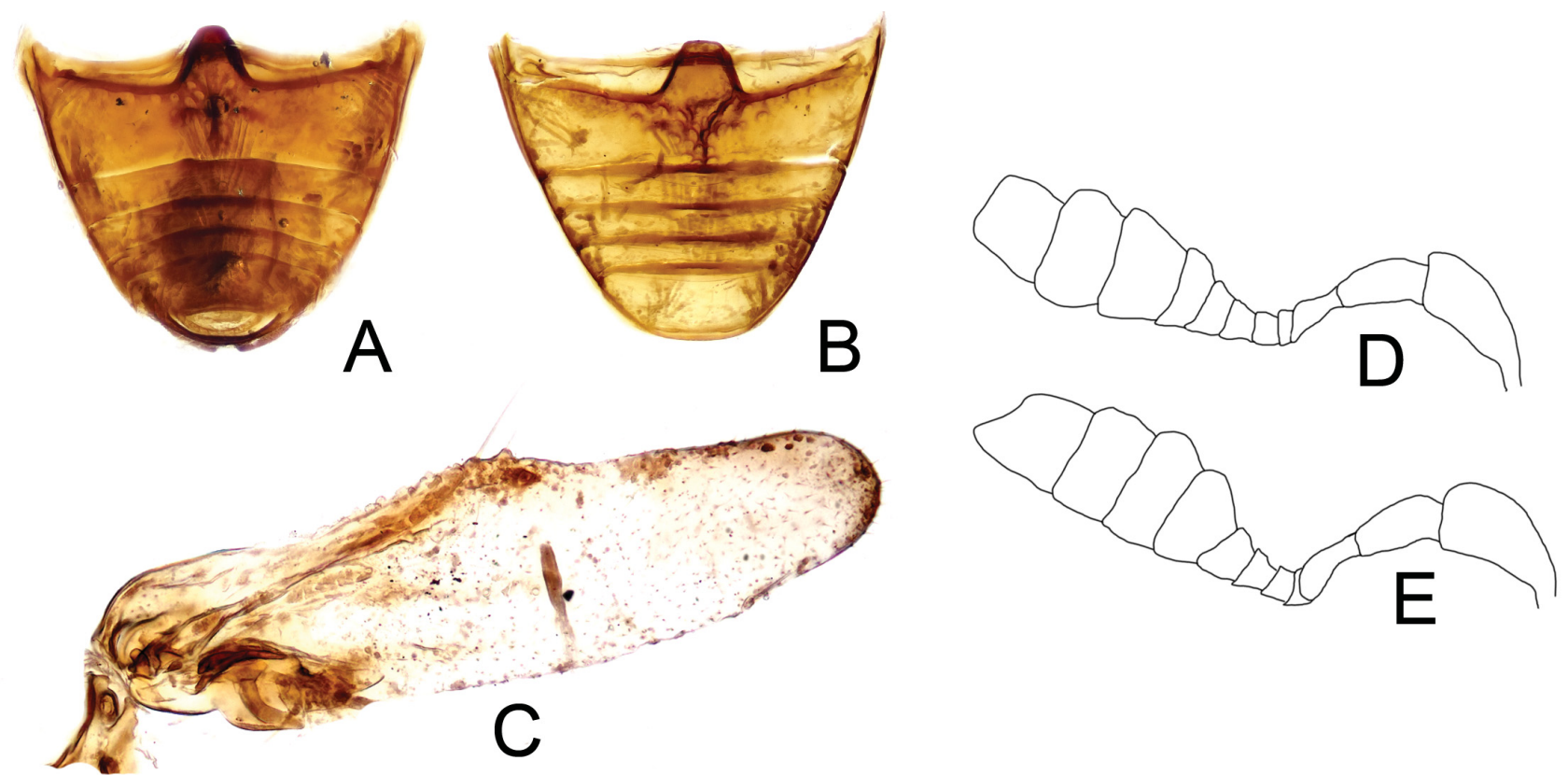

Fig. 5. Morphological differences between Clavicornaltica doeberli sp. nov. and C. longipenis sp. nov. A - abdomen of C. doeberli in ventral view; B abdomen of $C$; longipenis in ventral view; $\mathrm{C}$ - reduced wing of $C$. longipenis; $\mathrm{D}$ - antenna of $C$. doeberli; $\mathrm{E}-$ antenna of $C$. longipenis.
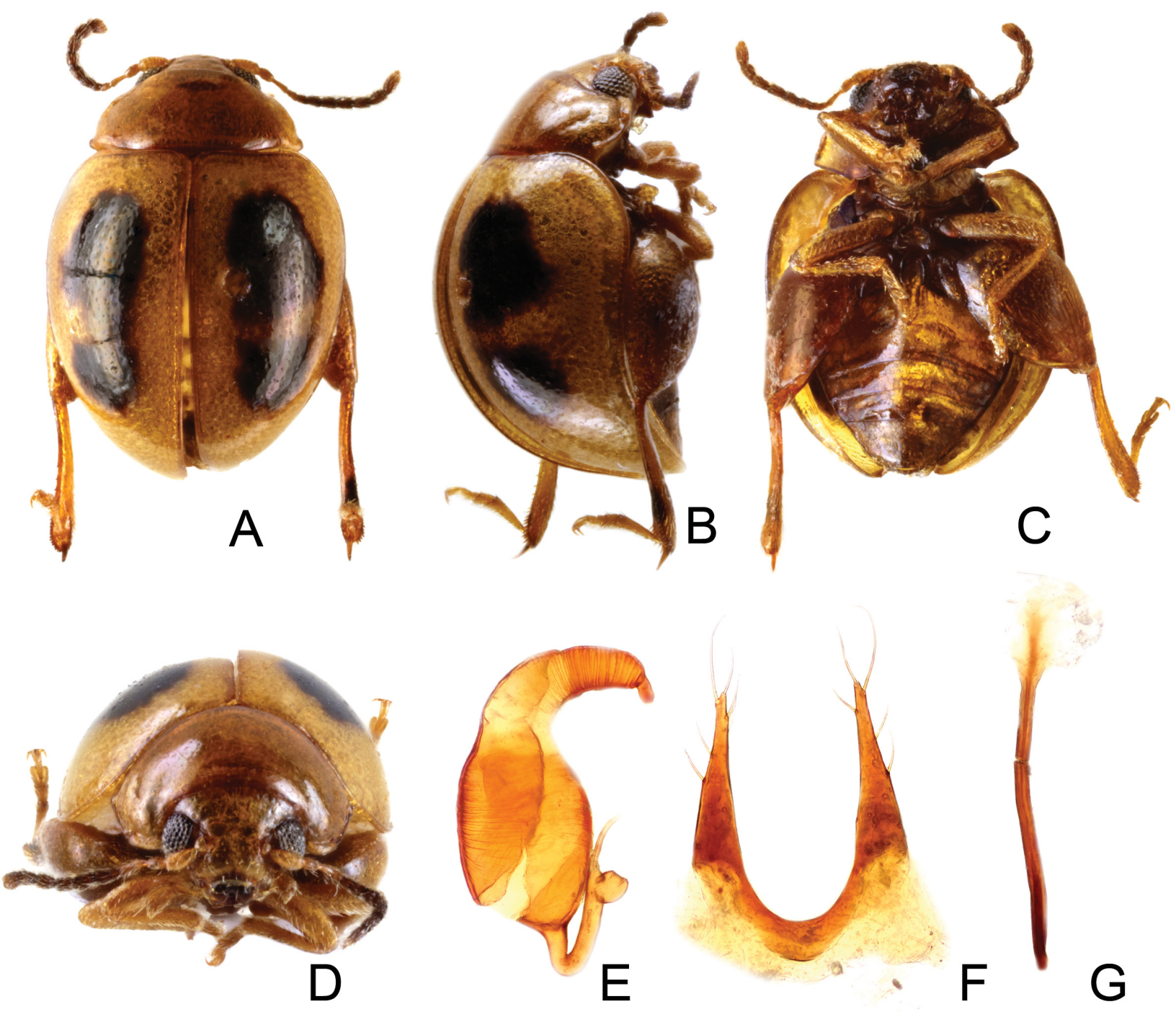

G

Fig. 6. Morphology of Ivalia excavata (Wang, 1993) specimen from Hong Kong. A - habitus in dorsal view; B - habitus in lateral view; C - habitus in ventral view; $\mathrm{D}$ - habitus in frontal view; $\mathrm{E}$ - spermatheca; $\mathrm{F}$ - vaginal palpi; $\mathrm{G}$ - tignum. 
Genitalia. Aedeagus (Figs 4G-H) extremely long, orificium basale reaching thorax, slender, curved apically, orificium basale extremely long and slender, forming $1 / 2$ to $2 / 3$ of the total length of aedeagus. Apex of aedeagus pointed. Spermatheca (Fig. 4D) small, with slender pump and bulbose receptacle, duct short, very robust, U-shaped. Vaginal palpi (Fig. 4F) connected basally, long, slender, bearing 3 long setae apically. Tignum (Fig. 4E) strong, long.

Etymology. The name of the species is inferred from the latin adjective longus meaning 'long' and noun penis, referring to the unusually long aedeagus of the species. The name is a noun in apposition.

\section{Ivalia excavata (Wang, 1993)}

(Fig. 6A-G)

Taizonia excavata Wang, 1993 in WANG \& YU $(1993: 321,329)$ (original description).

Ivalia excavata: DucKeTt et al. (2006: 51) (new combination)

Material examined. China: Hong Kong - New Territories, Shing Mun, moss, night time, 1.v.2009, 1 \%, Paul Aston lgt. (NMPC).

Remarks. Specimen identified as Ivalia excavata is the only member of the genus Ivalia collected in Hong Kong. It can be distinguished from similar Cangshanaltica by having the anterolateral pronotal setiferous pore placed near to the pronotal apex and by lacking any protrusion on antennomere VII. The specimen is also very easily distinguishable from $C$. sprynari sp. nov. by their light orange color with black spots on elytra and greater size.

The species Ivalia excavata is known from Hunan Province, China. We compared the specimen with pictures of the holotype deposited in Institute of Zoology, Chinese Academy of Sciences, Beijing. Another two species of Ivalia have been described from mainland China (Кімото \& GRESSIT 1973). The specimen collected in Hong Kong is, also very similar to one of those species - I. maculata (Kimoto \& Gressitt, 1973) based on the comparison with the original description. The identity of the specimen should be considered carefully because of the high endemism of Ivalia species and also the identity of the species needs to be revised (we were unable to study the holotype of I. maculata deposited in Bishop Museum, Honolulu, Hawaii). However, the specimen from Hong Kong differs from the original description of I. maculata in size ( $I$. maculata is about $1.8 \mathrm{~mm}$ long, Hong Kong specimen is about $2.3 \mathrm{~mm}$ long) and coloration (I. maculata seem to have dorsal surfaces and legs darker than specimen from Hong Kong). Genitalia were not illustrated in the original descriptions and cannot be compared. In this paper, we provide detailed pictures of Ivalia excavata specimen from Hong Kong for the first time, including pictures of female genitalia (Figs 6A-G). Further revision should reveal the correct status of this specimen.

\section{Discussion}

Taxonomical status of Cangshanaltica. Cangshanaltica sprynari sp. nov. was assigned to the genus Cangshanaltica due to the presence of the anterolateral pronotal setiferous pore present in the middle of the pronotal margin and the presence of a slight protrusion on antennomere VII.
However, the morphology of $C$. sprynari sp. nov. in fact combines characters of both Cangshanaltica and Ivalia. The genus Cangshanaltica is diagnosed from Ivalia in having the anterolateral pronotal setiferous pore in the middle of lateral pronotal margin (which is present in C. sprynari sp. nov.), but also by having a distal protrusion on antennomere VII (which is weakly developed in C. sprynari sp. nov.) and only slightly curved metatibiae (in $C$. sprynari sp. nov., metatibiae are strongly curved, resembling those of Ivalia). Cangshanaltica sprynari sp. nov. also has short and strongly divergent vaginal palpi, which is a character typical for Ivalia. Known Cangshanaltica species have parallel vaginal palpi (NADEIN 2013, KONSTANTINOV et al. 2013, DAmašKa \& Konstantinov 2016). The morphology of Cangshanaltica sprynari sp. nov. shows us that status of the genus Cangshanaltica (or at least the assignment of the newly described species to this genus) needs to be revised, optimally using the molecular phylogeny, to examine the relationships between the two genera. A comparative taxonomic revision of Ivalia and related genera seems also necessary.

Biology of moss-inhabiting flea beetles in Hong Kong. The distribution of Cangshanaltica sprynari sp. nov. in Wang Tong is very unique among moss-inhabiting flea beetles in Asia, because moss-inhabiting flea beetles are usually found in high mountain ranges, where they occur in montane mossy forests or in moss cushions in the subalpine zone, or at least in moist mountain valleys. Finding moss-inhabiting flea beetles in low elevations on islands is very rare. In the genus Ivalia only a single other case, Ivalia merkli (Medvedev, 1998) described from Pulau Tioman, a tropical island in Malaysia, where only lowland tropical forest is present (MEDVEDEV 1998). However, we don't have any information about the biology of this species, which prevents us to assume it as a moss feeder. The occurrence of Cangshanaltica sprynari sp. nov. and Ivalia merkli in lowlands on islands could be possible due to some very special conditions in some island microhabitats, allowing the presence of moss-inhabiting flea beetles normally found in mountains (e. g. some ravines with a strong supply of fog and cloud moisture coming from the sea). However, it can also show us that moss-inhabiting flea beetles use diverse ecological strategies and some species normally occur in lowlands, similarly to the European moss-inhabiting genus Mniophila Stephens, 1831 (NADEIN 2009). However, in Southeast Asia, there have been dozens of studies from various habitats examining ground-living insects, by leaf litter sifting, these studies have shown genera like Ivalia or Cangshanaltica are not widely present in lowland sifting samples. Therefore, the hypothesis of specific local conditions allowing small populations of usually montane beetles appears more likely. Further biodiversity research studies should lead to a better understanding of ecological and altitude preferences of moss-inhabiting flea beetles in Asia.

Because of high local endemism of moss-inhabiting flea beetles and their association with moss in forests or forest margins, it is very likely that Cangshanaltica sprynari sp. nov. is a very rare species, forming some small populations on Lantau, where the majority of forests was cleared. 

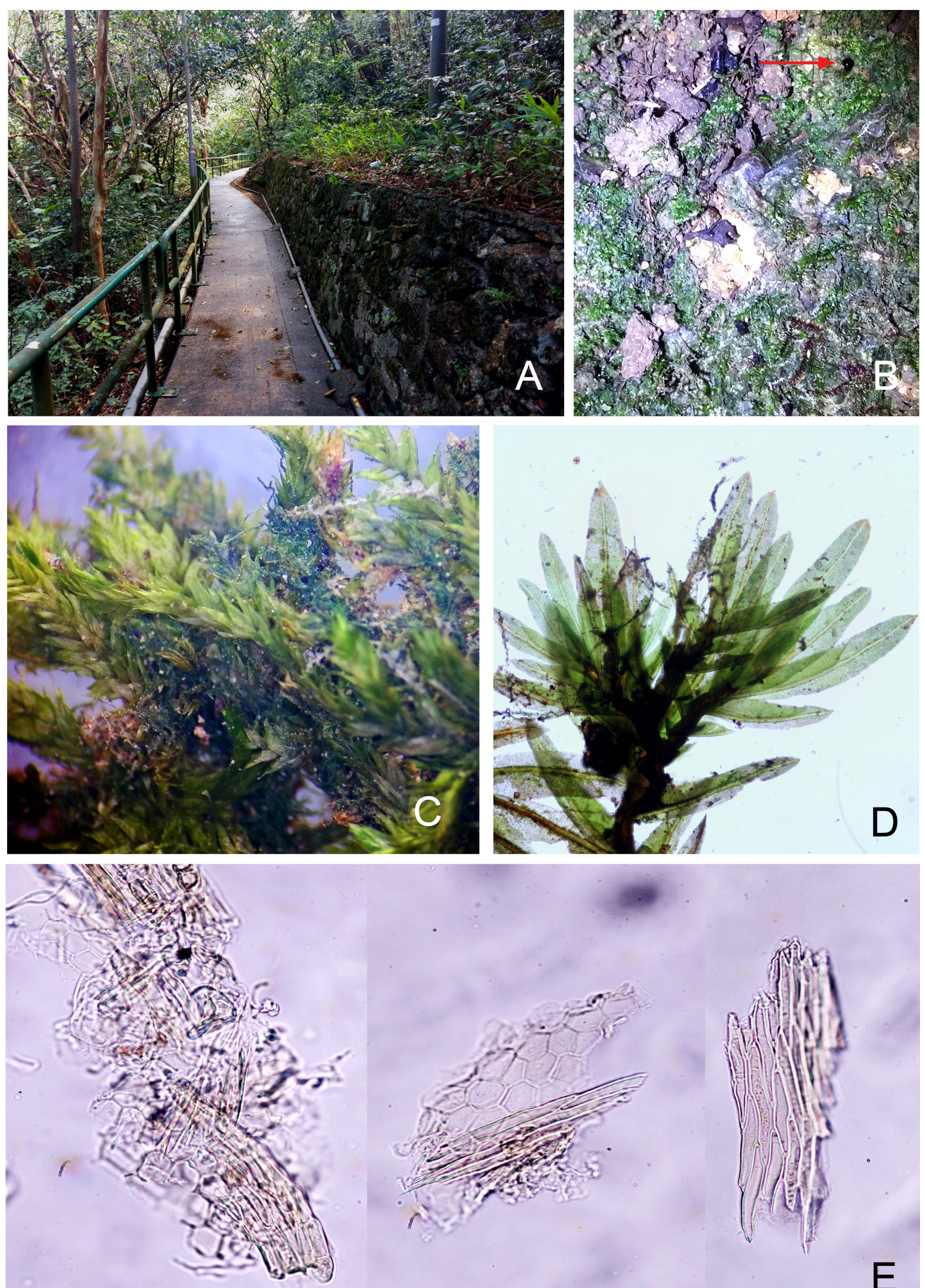

Fig. 7. Ecology and habitat of Cangshanaltica sprynari sp. nov.. A - type locality of C. sprynari in Mui Wo, Lantau, HK; B - a thin layer of moss with C. sprynari walking at night (red arrow); $\mathrm{C}-\mathrm{D}$ - Fissidens sp., the main host species of moss for C. sprynari; $\mathrm{E}-$ residua of moss tissues from the gut of C. sprynari. 
Small forest residua where C. sprynari sp. nov. was found should be therefore protected for avoiding extinction of this unique flea beetle species.

The life strategy of C. sprynari sp. nov. is also very interesting. Unlike most other moss-inhabiting flea beetles, this species does not appear to be dependent on moss cushions. It was found, walking on thin moss layers on rocks, when the moss is not dried out, instead of most moss-inhabiting flea beetles, collected in thick moss cushions, usually by sifting, or by pitfall traps in mossy forests. This shows that diversity of moss-inhabiting flea beetles can be even higer than we expected and many species can be very difficult to collect.

Syntopic occurrence of Clavicornaltica species. Clavicornaltica longipenis sp. nov. was found to live sympatrically with the species $C$. doeberli sp. nov. and both are superficially similar in external morphology, although the very different morphology of both male and female genitalia seem to indicate they are not closely related. This shows that more than one species of Clavicornaltica can occur together in the same place and all specimens in one series need to be dissected. This also concerns, the type series of previously described species, in which not all, if any of the specimens were dissected. They may consist of multiple species and a careful revision of the known species is therefore necessary.

\section{Acknowledgements}

We are very thankful to Yong-Ying Ruan (Chinese Academy of Sciences, Beijing), who contributed to the publication by sending pictures of the holotype of Ivalia excavata from Beijing. We thank Zdeněk Soldán (Charles University, Prague) for identification the Fissidens sp. moss. We also thank Martin Fikáček (Charles University, Prague and National Museum, Prague) for his advice and comments to improve the manuscript. The project was supported by the grants SVV 260 434/2018 and GAUK $243-250932$ to AFD.

\section{References}

ASTON P. 2009: Chrysomelidae of Hong Kong Part 2 Subfamily Alticinae. Hong Kong Entomological Bulletin 1: 1-13.

DAMAŠKA A. \& KONSTANTINOV A. 2016: A new species of Cangshanaltica Konstantinov et al., a moss-inhabiting flea beetle from Thailand (Coleoptera: Chrysomelidae: Galerucinae: Alticini). Zootaxa 4107: 93-97.
DUCKETT C. N., PRATHAPAN K. D. \& KONSTANTINOV A. S. 2006: Notes on identity, new synonymy and larva of Ivalia Jacoby (Coleoptera: Chrysomelidae) with description of a new species. Zootaxa 1363: 49-68.

GRESSITT J. L. \& KIMOTO S. 1963: The Chrysomelidae (Coleoptera) of China and Korea. Pacific Insects Monograph 1B: 301-1026.

KONSTANTINOV A. S. \& CHAMORRO-LACAYO M. L. 2006: A new genus of moss-inhabiting flea beetles (Coleoptera: Chrysomelidae) from the Dominican Republic. Coleopterists Bulletin 60: 275-290.

KONSTANTINOV A., CHAMORRO M. L., PRATHAPAN K. D., GE S. \& YANG X. 2013: Moss-inhabiting flea beetles (Coleoptera: Chrysomelidae: Galerucinae: Alticini) with description of a new genus from Cangshan, China. Journal of Natural History 47: 37-41.

KONSTANTINOV A. S. \& DUCKETT C. N. 2005: New species of Clavicornaltica Scherer (Coleoptera: Chrysomelidae) from continental Asia. Zootaxa 1037: 49-64.

KONSTANTINOV A. S. \& KONSTANTINOVAA. A. 2011: New genus and species of flea beetles (Coleoptera, Chrysomelidae, Galerucinae, Alticini) from Puerto Rico, with comments on flea beetle diversity in the West Indies and a key to the West Indian Monoplatini genera. ZooKeys 155: 61-87.

LAWRENCE J. F., BEUTEL R. G., LESCHEN R. A. B. \& ŚLIPIŃSKI A. 2010: Glossary of morphological terms. Pp. 9-20. In: LESCHEN R. A. B., BEUTEL R. G. \& LAWRENCE J. F. (eds): Handbook of Zoology, Coleoptera, Volume 2. Morphology and Systematics (Elateroidea, Bostrichformia, Cucujiformia partim). Walter de Gruyter, Berlin, 786 pp.

LINZMEIER A. M. \& KONSTANTINOV A. S. 2018: Andersonoplatus, a new, remarkable leaf litter inhabiting genus of Monoplatina (Coleoptera, Chrysomelidae, Galerucinae, Alticini). ZooKeys 744: 79-138.

MEDVEDEV L. N. 1996: Review of the flea-beetle genus Clavicornaltica Scherer, 1974 (Coleoptera: Chrysomelidae, Alticinae). Zeitschrift für Entomologie 17: 137-148.

MEDVEDEV L. N. 1998: New Chrysomelidae (Coleoptera) from Southeast Asia in the Hungarian Natural History Museum. Annales Historico-Naturales Musei Nationalis Hungarici 90: 163-174.

NADEIN K. S. 2009: Revision of the genus Mniophila Stephens, 1831. Beiträge zur Entomologie 59: 103-131.

NADEIN K. S. 2013: Ivalia Jacoby - a flea beetle genus new to Australia (Coleoptera: Chrysomelidae: Galerucinae). Zootaxa 3669: 384-400.

RUAN Y., KONSTANTINOV A., PRATHAPAN K. D. \& YANG X. 2017: Contributions to the knowledge of Chinese flea beetle fauna (II): Baoshanaltica new genus and Sinosphaera new genus (Coleoptera, Chrysomelidae, Galerucinae, Alticini). Zootaxa 4282: 111-122.

SCHERER G. 1974: Clavicornaltica, a new genus from Ceylon (Coleoptera: Chrysomelidae: Alticinae). Revue Suisse de Zoologie 81: 57-68.

SUENAGA H. \& YOSHIDA T. 2016: Two new species of the genus Clavicornaltica (Coleoptera, Chrysomelidae, Galerucinae) from Taiwan and Ishigaki-jima Island, Japan. Elytra 6: 1-9.

WANG S.-Y. \& YU P.-Y. 1993: Coleoptera: Chrysomelidae - Alticinae. Pp. 315-330. In: HUANG F.-S. (ed.): Insects of Wuling Mountains area, southwestern China. Science Press, Beijing, $\mathrm{x}+777$ pp. (in Chinese, English summary). 
